\title{
HAK ASASI MANUSIA DAN PEKERJAAN SOSIAL
}

Oleh:

Eva Nuriyah Hidayat ${ }^{10}$

\section{Abstrak}

Hak asasi manusia dan pekerjaan sosial merupakan suatu hal yang saling berkaitan, dimana pekerjaan sosial di dalam prakteknya mendasarkan etika pada hak asasi manusia. Dalam praktek pekerjaan sosial, permasalahan yang muncul adalah hak asasi manusia yang seperti apa yang dapat diterapkan sebagai etika praktek pekerjaan sosial. Oleh karena itu mahasiswa perlu dibekali dasar-dasar hak asasi manusia yang sesuai dengan sistem sosial masyarakat.

\footnotetext{
${ }^{10}$ Disampaikan dalam Seminar "Social Work Students Sensitized Orientation on Human Rights", yang diselenggarakan Jurusan IImu Kesejahteraan Sosial FISIP UNPAD bekerja sama dengan Ikatan Pendidikan Pekerjaan Sosial Indonesia, pada tanggal 13 Desember 2012 di Gedung D Lt II FISIP UNPAD Jatinangor.
} 


\section{A. Pendahuluan}

Manusia adalah makhluk paling
sempurna dari aspek penciptaan dan
kedudukannya $^{11}$. la adalah makhluk yang
terdiri atas unsur lahir dan batin, jasmani dan rohani (sebagian menyebutnya menambah unsur nafsani), merupakan makhluk tertinggi ciptaan Allah yang merupakan citra ArRahman $^{12}$ (Suratir Rahman). Sebelum kelahirannya telah didahului oleh perjanjian primordial dengan $\operatorname{Tuhan}^{13}$, sehingga ia terlahir dengan berkeimanan dengan fitrah suci yang dengan bekal akal budi dan hati nuraninya potensial berlaku lurus ${ }^{14}$.

11 Mengenai hal ini banyak ayat Al Qur-an ataupun Hadits Rasul yang bisa dirujuk. Salah satu yang terkenal adalah, "Sesungguhnya manusia diciptakan dalam sebaik-baik kejadian". Qur-an S. At- Tien: 5.

12 Dalam Teologi Kristiani juga ada pandangan ini. Magnis Suseno misalnya menyebut "Manusia diciptakan oleh Allah menurut CitraNya" atau "Bahwa manusia diciptakan menurut citra Allah". Lihat Franz Magnis Suseno. Kuasa \& Moral. Jakarta: PT Gramedia Pustaka Utama, 2001. h. 14-15

13 Istilah perjanjian primordial adalah istilah yang ditemkan Prof Nurcholish Madjid, untuk menyebut perjanjian perjanjain Tuhan dengan segenap Roh sebagaimana dilukiskan dalam Qur-an, Surat Al A'raf (7) ayat 172-173.

14 Kesucian asal itu bersemayam dalam hati nurani (nurani, artinya bersifat cahaya terang), yang mendorongnya untuk senantiasa mencari, berpihak dan berbuat baik dan benar. Jadi setiap pribadi mempunyai potensi untuk benar(Qur-an S. Al Ahzab/33:4). Maka, untuk hidupnya, manusia dibekali akal pikiran, kemudian agama, dan terbebani kewajiban terus menerus mencari dan memilih jalan hidup yang lurus, benar dan baik. Karena itu diwajibkan mengerjakan shalat, yang didalamnya harus membaca al Fatihah. Dalam surat itu ada doa yang harus dihayati dengan sepenuh hati dann diaminkan, yaitu doa memohon jalan yang lurus. Mencari, menemukan, memahami dan mengikuti jalan yang lurus adalah perjalanan yang
Manusia juga hadir ke dunia dengan mengemban amanah, sebagai khalifah Tuhan yang dengan segala kelebihannya Tuhan pun menanggungnya. Karena itu sampai setelah kematiannya manusia harus tetap dihormati, dengan segala hak yang dimilikinya. Sebagian hak-haknya merupakan hak asasi (Hak Asasi Manusia-HAM) ${ }^{15}$. Inilah yang disebut hak asasi manusia yaitu hakhak yang telah dipunyai seseorang sejak ia dalam kandungan dan merupakan pemberian Tuhan.

Istilah hak asasi manusia bukan hanya istilah yang dipergunakan oleh masyarakat barat saja. Ide untuk memperjuangkan hak dan martabat, hak untuk hidup, hak memperoleh keadilan, hak memperoleh kemerdekaan, hak memperoleh persamaan dan hak untuk memperoleh perlindungan merupakan hak-hak yang tidak hanya diperjuangkan oleh semua bangsa. Von Senger menyatakan bahwa di berbagai belahan dunia dan di berbagai kultur di dunia ini, istilah hak asasi manusia dikenal oleh

tidak kenal berhenti. Maka shalat yang mencakup doa tersebut juga tidak berhenti, terus menerus sepanjang hayat (Surat Al Fatihah: ayat 7).

${ }^{15}$ Hak asasi manusia (HAM) adalah seperangkat hak yang melekat pada hakikat dan keberadaan manusia sebagai makhluk Tuhan Yang Maha Esa dan merupakan anugerah-Nya yang wajib dihormati, dijungjung tinggi, dan dilindungi oleh negara, hukum, pemerintah, dan setiap orang demi kehormatan serta perlindungan harkat dan martabat manusia (Pasal 1 angka 1 UU No. 39 Tahun 1999 tentang Hak Asasi Manusia). 
semua manusia, meskipun penamaannya atau istilahnya berbeda. ${ }^{16}$

\section{B. Hak Asasi Manusia di Indonesia}

Hak Asasi Manusia di Indonesia bukanlah suatu wacana yang asing dalam pembentukan bangsa. Jauh sebelum kemerdekaan, para founding fathers telah memperjuangkan harkat dan martabat manusia ke arah yang lebih baik, misalnya RA. Kartini dalam surat-suratnya, Ki Hajar Dewantara, dan para pejuang yang memperjuangkan kemerdekaan bangsa. Titik tolak Bangsa Indonesia dalam memperjuangkan Hak Asasi Manusia adalah berdasarkan pemahaman bahwa bangsa Indonesia lahir dan memperjuangkan hak dasar ini, terutama hak untuk merdeka. Dan hal ini tidak hanya terbatas pada hak atas kebebasan politik namun juga kebebasan dari kemelaratan, kebodohan, ketidakadilan sosial dan keterbelakangan ekonomi.

Konsep Indonesia mengenai HAM muncul dari dasar filsafat negara, Pancasila, terutama dari sila keduanya yakni kemanusiaan yang adil dan beradab. Hal ini kemudian terefleksi juga di dalam 4 sila lainnya yang secara bersama-sama mensiratkan gagasan mengenai harkat dan martabat manusia baik sebagai anggota masyarakat dan individu.

\footnotetext{
${ }^{16}$ Von Senger. H. 1993. "From the Limited to The Universal Consept of Human Rights: Two Periods of Human Rights" in Schmale, Human Rights and Cultural Diversity. HIm: 47.
}

Indonesia tidaklah berbeda dengan negara-negara Asia dan Afrika lainnya yang pernah mengalami kemajuan budaya, namun tidak mengalaminya pada periode yang sama dengan negara-negara barat dalam mengembangkan gagasan demokrasi dan HAM. Oleh karenanya, negara-negara Asia dan Afrika, terkadang memiliki persepsi yang berbeda, dikarenakan pengalaman yang berbeda tersebut terkait dengan hubungan antara negara dan masyarakat, manusia dan sesama manusia dan hak-hak masyarakat yang diperlawankan dengan hak-hak individualistis.

Hak Asasi Manusia yang berkesesuaian dengan Pasal 29 dari Universal Declaration of Human Right yang menekankan pada dua aspek yang harus selalu diseimbangkan. Pada satu sisi, terdapat prinsip-prinsip yang sangat terkait dengan hak-hak dasar dan kebebasan individu, namun pada sisi lain, terdapat pernyataan terkait dengan kewajiban bagi individu terhadap masyarakat dan negara. Implementasi HAM menuntut adanya hubungan yang saling seimbang antara hakhak individual dan kewajibannya terhadap masyarakat. Tanpa adanya keseimbangan, hak komunitas secara keseluruhan tidaklah dapat dikesampingkan, hal ini dapat menciptakan ketidakstabilan dan bahkan anarki, terutama bagi negara-negara berkembang. Di Indonesia, seperti di banyak negara berkembang lainnya, hak-hak individu adalah seimbang dengan hak dari masyarakat. Budaya Indonesia berdasarkan 
hukum kebiasaan para leluhurnya, selalu mengedepankan hak dan kepentingan masyarakat dan bangsa. Namun demikian, hal ini dilakukan tanpa meminimalkan hakhak dan kepentingan-kepentingan dari individu-individu dan kelompok-kelompok minoritas. Kepentingan dari kelompok terakhir yang disebutkan selalu diperhitungkan atas dasar prinsip musyawarah mufakat, yang terkandung di dalam sistem politik dan bentuk demokrasi Bangsa Indonesia.

Indonesia tidak bermaksud mengusulkan konsep alternatif HAM, selain yang telah disepakati oleh negara-negara PBB. Indonesia sejak 1991 merupakan anggota Komisi HAM PBB, dan mengakui peran penting yang dapat dimainkan oleh institusi nasional dalam rangka mempromosikan dan melindungi HAM, Indonesia pada tahun 1993 membentuk Komisi Nasional Hak Asasi Manusia. Oleh karenanya Indonesia menerima dan mengakui keabsahan universal dari HAM dasar dan kebebasan dasar. Namun demikian, Indonesia menekankan pada perlu dilakukannya pengakuan yang luas terhadap kompleksitas dari isu HAM yang muncul dikarenakan kebergamaan yang luas, baik dari sejarah, budaya, sistem nilai, lokasi geographis dan tahap-tahap perkembangan antara negara-negara di dunia. Oleh karenanya, seluruh negara-negara harus memiliki sensitifitas dari menghadapi kompleksitas dari Isu HAM yang muncul.
Sejalan dengan pandangan ini, Indonesia mendukung penuh kebijakan yang temuat di dalam Piagam PBB yang mempromosikan dan perlindungan HAM dalam konteks kerjasama internasional. Saat ini telah terdapat beragam kovensi-konvensi, deklarasi-deklarasi dan pengertian yang sama dalam mengimplementasikan dan mengukur kerjasama internasional yang dikembangkan oleh PBB sejak tahun 1945. Indonesia melihat hal ini merupakan representasi dari pemulaan budaya universal atas HAM yang merupakan dasar bagi terciptanya kerjasama internasional dalam isu HAM.

Namun demikian, kerjasama internasional, mensyaratkan penghargaan bagi kedaulatan yang setara dari negaranegara dan identitas nasional dari suatu bangsa. Indonesia oleh karenanya, memegang pandangan bahwa kerjasama internasional, tidak boleh dilakukan atas dasar tuduhan yang tidak mendasar, pengkhotbahan yang hanya berdasar pada kehendak sendiri, atau pencampuran (intervensi) terhadap negara lain. Tidak ada suatu negara atau sekelompok negaranegara memegang peran sebagai hakim maupun juri atas negara lain, hal ini merupakan hal yang penting dan sensitif.

\section{Pendidikan Hak Asasi Manusia di Jurusan IImu Kesejahteraan Sosial}

HAM menjadi bahan yang kian meluas diperbincangkan di berbagai 
kalangan masyarakat. Namun yang paling mendominasi perhatian pembahasan materi/subtansinya berpusat di dunia akademik, suatu tempat penggodokan calon pemimpin masa depan -sebagai dosen, pengacara, konsultan, legal drafter, legislator, pejabat, notaris, dan lain-lain- yang akan memiliki tempat dan pengaruh tersendiri di kalangan masyarakat. Titik sentral permasalahannya meliputi sejarah, teori-teori, kandungan aturan hukumnya sampai pada pelaksanaannya.

Secara umum, pengajaran mata kuliah HAM ini harus sejalan dengan tujuan Pendidikan Nasional sebagaimana yang tertuang dalam pasal Pasal 3 UU No. 20 Tahun 2003 tentang Sistem Pendidikan Nasional (UU Sisdiknas). Pasal 3 menyatakan,

\begin{abstract}
"Pendidikan nasional berfungsi mengembangkan kemampuan dan membentuk watak serta peradaban bangsa yang bermartabat dalam rangka mencerdaskan kehidupan bangsa, bertujuan untuk berkembangnya potensi peserta didik agar menjadi manusia yang beriman dan bertakwa kepada Tuhan Yang Maha Esa, berakhlak mulia, sehat, berilmu, cakap, kreatif, mandiri, dan menjadi warga negara yang demokratis serta bertanggung jawab"
\end{abstract}

Berdasarkan hal itu, pengajaran ini secara umum untuk membekali mahasiswa ilmu/pengetahuan tentang HAM yang meliputi sejarah, teori-teori (termasuk ham partikularistik-universal), kandungan aturan hukumnya sampai pada pelaksanaannya. Pengajaran tersebut, saat ini telah diberikan pada berbagai universitas di Fakultas Hukum. Khusus di Jurusan Ilmu Kesejahteraan Sosial FISIP UNPAD, pendidikan hak asasi manusia diberikan kepada mahasiswa dalam judul mata kuliah "Pekerjaan Sosial dan Hak Asasi Manusia". Meskipun mata kuliah tersebut berupa mata kuliah pilihan dan baru dilaksanakan pada tahun ini, namun terdapat hal-hal yang penting dari substansi perkuliahan yang garis besar matakuliah ini terbagi menjadi:

1. Pengetahuan dasar tentang HAM, meliputi sejarah, teori-teori, dan aturanaturan HAM nasional dan internasional, dengan materi ini diharapkan mahasiswa dapat memahami konsep HAM secara utuh.

2. Permasalahan-permasalahan yang melanggar HAM baik lokal, nasional maupun internasional. Permasalahan yang dibahas meliputi kejahatan genosida dan kejahatan kemanusiaan yang ada di masyarakat. Dengan materi ini diharapkan mahasiswa kritis terhadap permasalahan-permasalahan HAM yang dialami baik oleh individu, kelompok maupun masyarakat.

3. Sistem sosial budaya masyarakat dan Hak Asasi Manusia, dengan materi ini diharapkan mahasiswa memahami bahwa hak asasi manusia itu tidak terlepas dari kultur budaya masyarakat.

4. Praktek pekerjaan sosial dan Hak Asasi Manusia, materi ini meliputi human rights and human need, etics and human rights, dan beberapa praktek pekerja 
sosial di lembaga-lembaga nasional maupun internasional. Dengan materimateri tersebut diharapkan mahasiswa dapat lebih memahami praktek pekerjaan sosial serta dapat menumbuhkan kesadaran bagi mahasiswa sebagai calon pekerja sosial akan harkat martabat kemanusiaan para pribadi, sehingga dalam memberikan pertolongan ataupun intervesi tidak melanggar hak-hak asasi manusia.

Berkaitan dengan sosialisasi dan penegakan hak asasi manusia telah ada pengaturannya di dalam Pasal 100 UndangUndang No. 39 Tahun 1999, yang menyatakan sebagai berikut :

Setiap orang, kelompok, organisasi politik, organisasi masyarakat, lembaga swadaya masyarakat, atau lembaga kemasyarakatan lainnya, berhak berpartisipasi dalam perlindungan, penegakan,dan pemajuan Hak Asasi Manusia.

Lebih lanjut Pasal 103 UU No. 39

Tahun 1999 menyebutkan,

Setiap orang, kelompok, organisasi politik, organisasi masyarakat, lembaga swadaya masyarakat, perguruan tinggi, lembaga studi atau lembaga kemasyarakatan lainnya, baik secara sendiri-sendiri maupun bekerjasama dengan Komnas HAM dapat pula melakukan penelitian, pendidikan, dan penyebarluasan informasi mengenai Hak Asasi Manusia.

Kedua ketentuan di atas, menunjukkan bahwa sosialisasi dan penegakan hak asasi manusia tidak hanya menjadi tanggungjawab negara tetapi setiap orang, kelompok, organisasi politik, organisasi masyarakat, lembaga swadaya masyarakat, perguruan tinggi, juga turut mempunyai hak untuk ikut melakukan sosialisasi dan penegakan hak asasi manusia.

\section{Peluang dan Tantangan Bagi Praktek Pekerja Sosial}

Selaku makhluk individual dan makhluk sosial, ia perlu berproses menuju pencapaian jatidirinya. Dalam proses ini termasuk melalui pendidikannya- ia akan mengalami berbagai benturan. Ada kalanya ia sanggup mengatasi, ada kalanya ia tak sanggup menghadapinya. Akibatnya banyak fakta yang mengungkap berbagai pelanggaran oleh manusia, baik pelanggaran sederhana maupun kejahatan berat. Baik yang dilakukan oleh individu maupun yang telah memegang jabatan.

Berbagai bentuk pelanggaran yang diterima oleh korban baik yang dilakukan oleh aparat atau bukan, ke Komisi Nasional Hak Asasi Manusia (Komnas HAM) tahun 2008 mencapai jumlah 4900 kasus, dan sampai tahun 2009 data pelanggaran HAM yang dilaporkan ke Komnas HAM ini mengalami peningkatan yaitu mencapai 5300 kasus ${ }^{17}$. Hal ini cukup memprihatinkan mengingat berbagai bentuk pelanggaran HAM ini tidak

\footnotetext{
${ }^{17}$ Laporan Komnas HAM 2009.
} 
semuanya mendapatkan pelayanan dan advokasi yang maksimal.

Kondisi tersebut menjadi suatu tantangan bagi profesi pekerjaan sosial. Pekerjaan sosial sebagai sebagai profesi pemberian bantuan untuk penyelesaian masalah, pemberdayaan dan mendorong perubahan sosial dalam interaksi manusia serta lingkungannya pada tingkat individu, keluarga, kelompok dan masyarakat untuk meningkatkan kesejahteraannya. Pekerjaan sosial mendasarkan intervensinya pada teori perilaku manusia dan lingkungan sosial serta prinsip-prinsip hak asasi manusia dan keadilan dengan memperhatikan faktor budaya masyarakat.

Berdasarkan definisi tersebut maka hak asasi manusia merupakan dasar moral praktek pekerjaan sosial baik level personal, community development maupun advokasinya. ${ }^{18}$ Hal-hal yang terkait dengan HAM ini adalah democracy, justice, feedom, equality and human dignity, menjadi prinsipprinsip yang dijunjung oleh pekerja sosial. ${ }^{19}$ Berbicara mengenai hak asasi manusia dalam profesi pekerjaan sosial tentu saja tidak terlepas dari konsep dan praktek pekerjaan sosial. Perspektif hak asasi manusia menjadi hal yang ditekankan dalam pertolongan individu dalam memperoleh tujuan dari kesejahteraan sosial.

\footnotetext{
${ }^{18}$ Ife, James William. 2001. Human Rights and Social Work. Toward Rights-Based Practice. UK: Cambridge University Press.

${ }^{19}$ Schmale.W (ed). 1993. Human Rights and Cultural Diversity, Goldbach, Germany: Keip.
}

Berbagai kasus pelanggaran hak asasi manusia di Indonesia masih banyak yang belum mendapatkan pelayanan dan perlindungan. Apalagi pelanggaranpelanggaran hak asasi manusia berat (genosida) yang melibatkan para penguasa (dalam hal ini pemerintah), misalnya pembantaian masal pada tahun 1965-1970, kejadian di Timor Timur (April 1999), Tanjung Priok (1984), kasus Bulu Kumba, kasus Trisakti, dan masih banyak lagi kasus kemanusian seperti kasus Marsinah, perdagangan anak, dan lain-lain. Sederet penanganan di atas belumlah mendapat penanganan yang berarti. Secara garis besar masih jalan di tempat. Lembaga-lembaga, baik lembaga negara seperti Komnas HAM maupun lembaga non pemerintah / LSM hanya mampu mencatat data-data pelanggaran tanpa adanya kemajuan yang berarti dalam konteks penegakan HAM. Seperti yang disampaikan ELSAM (2007), tidak adanya kemajuan penanganan HAM adalah karena tidak koheren dan tidak konsistennya instansi-instansi negara dalam membuat kebijakan. Ada dua hal penyebabnya yaitu pemerintah sendiri kesulitan dalam mengimplementasikan kebijakan yang telah dibuat dan institusiinstitusi yang seharusnya dibentuk untuk mengimplementasikan kebijakan di bidang HAM, tidak bisa dibentuk karena tidak tersedianya sarana dan prasarana pembentukannya. Jikapun institusi itu dibentuk, institusi itu tidak bisa bekerja dengan baik karena tidak mendapat dukungan dan sarana yang baik. 
Penulis mengambil contoh mengenai hak pengungsi di Indonesia. Di tingkat nasional, hak asasi pengungsi tidak dicantumkan secara khusus. Kebijakan, program, pelayanan yang diberikan bagi pengungsi terkait hak asasinya dibuat secara umum dalam UU No. 39 Tahun 1999 Pasal 5 ayat (3) yang menyatakan bahwa setiap orang termasuk kelompok masyarakat yang rentan memperoleh perlakuan dan perlindungan yang lebih karena kekhususannya. Dalam Keputusan Presiden Republik Indonesia tentang Badan Koordinasi Nasional Penanggulangan Bencana dan Penanganan Pengungsi dimuat aturan mengenai penanganan pengungsi yang meliputi upaya pelayanan dan perlindungan kemanusiaan terhadap pengungsi yang timbul akibat konflik yang terjadi di suatu daerah termasuk kegiatan pencegahan, tanggap darurat, penghapusan, pemindahan dan relokasi pengungsi. Pengungsi yang dimaksud dalam aturan ini lebih dikenal dengan istilah korban konflik atau korban bencana sosial. Dalam Kepres tersebut belum diatur secara khusus penanganan dan pelayanan kemanusiaan bagi korban pengungsi bencana alam. Apabila kebijakannya masih belum diatur, bagaimana membuat perlindungan terhadap hak-hak bagi pengungsi. Setelah diberikan sekedar bantuan, banyak sekali pengungsi korban bencana alam ini diabaikan begitu saja.

Hal ini menjadi tantangan bagi pekerja sosial dalam menjalankan praktek pertolongan dan pemberdayaan. Sudah sejauh manakah peran pekerja sosial dalam menghadapi permasalahan hak asasi manusia yang begitu banyak di Indonesia.

Selain tantangan yang dihadapi, sebenarnya peluang pekerja sosial untuk berkiprah di dalam penanganan masalah HAM ini sebenarnya masih terbuka lebar. Berbagai organisasi non pemerintah (NGO) yang murni memperjuangkan HAM seperti ELSAM, Kontras, dan lain-lain, serta organisasi-organisasi yang menangani permasalahan secara khusus seperti masalah anak (Save the Children, UNICEF, dan lain-lain), masalah perempuan (UNIFEM ), masalah pengungsi (UNHCR ) dan lainlain, masih memerlukan profesi pekerjaan sosial.

\section{E. Penutup}

Pendidikan Hak Asasi Manusia bagi mahasiswa Jurusan IImu Kesejahteraan Sosial merupakan hal yang penting sebagai dasar moral praktek pekerjaan sosial. Dengan mata kuliah ini diharapkan mahasiswa dapat lebih memahami praktek pekerjaan sosial serta dapat menumbuhkan kesadaran bagi mahasiswa sebagai calon pekerja sosial akan harkat martabat kemanusiaan para pribadi, sehingga dalam memberikan pertolongan ataupun intervesi tidak melanggar hak-hak asasi manusia.

Peluang dan tantangan praktek pekerjaan sosial yang menangani permasalahan hak asasi manusia di 
Indonesia masih terbuka lebar, khususnya dalam organisasi-organisasi non pemerintah.

\section{DAFTAR PUSTAKA}

Ife, James William. 2001. Human Rights and Social Work. Toward Rights-Based Practice. UK: Cambridge University Press.

Laporan Komnas HAM 2009.
Schmale.W (ed). 1993. Human Rights and Cultural Diversity, Goldbach, Germany: Keip.

Von Senger. H. 1993. "From the Limited to The Universal Consept of Human Rights: Two Periods of Human Rights" in Schmale, Human Rights and Cultural Diversity. 